Jurnal MeA (Media Agribisnis), 5(1), April 2020, pp.62-73

Media Komunikasi Hasil Penelitian Bidang IImu Agribisnis

ISSN 2548-7027 (Print) | ISSN 2541-6898 (Online)

DOI 10.33087/mea.v5i1.62

\title{
USAHATANI SINGKONG (Manihot utilissima) \\ DI KELURAHAN BAGAN PETE KECAMATAN ALAM BARAJO KOTA JAMBI DITINJAU DARI SISI EKONOMI
}

\author{
${ }^{1 *}$ Rogayah, ${ }^{1}$ Wiwin Alawiyah dan ${ }^{2}$ Septiana Wisnu \\ ${ }^{1}$ Program Studi Agribisnis, Fakultas Pertanian Universitas Batanghari \\ ${ }^{2}$ Alumni Program Studi Agribisnis,Fakultas Pertanian Universitas Batanghari \\ Jl.Slamet Riyadi,Broni Jambi.36122.Telp. +62074160103 \\ 1*e-mail korespondensi : rogayah.gayah1959@gmail.com
}

\begin{abstract}
This reseaech was conducted with the aim tofind outdescriptin ofcasava farming and economic aspects (income, $R / C$ ratio, Break Event Poin (BEP) and PaybackPeriod (PP), in Bagan Pete Village, Alam Barajo Subdistrict, Jambi City. The researchobjective was to determine income, $R / C$ ratio $B E P$ and Payback Period. The resuts showed that the average cassava farming income was $R p$ 13,703,931/MT,with anaverage income of $R p$ 13,976,351/MT, the value of $R / C$ Ratio obtained was 51.3, the business was said to be unprofitable,but it described an inadequate income, because with capital of $R p$ 272,420 obtained sales results of 51 time or equivalent to Rp13,976,351. BEP of production is $90.80 \mathrm{Kg}$. $M T$,meaning that thelowest price that must be achieved so that farmers do not experiencelosses is $90.80 \mathrm{Kg} / \mathrm{MT}$. BEP price of $\mathrm{Rp} 58.4$ / Kg, meaning the lowest price that must be achieved so that farmers do not experience losses is $R p 58.4$ $/ K g$, while the Payback Period (PP) of 0,05 < 7,8, the business is said to be feasible because the payback period value is smaller that the economic age average tool,meaning that the timerequired to retur the investment itsef is not up to $7.8 \mathrm{MT}$
\end{abstract}

Keywords: study, Farming,Casava

\begin{abstract}
Abstrak
Penelitian ini dilakukan di Kelurahan Bagan Pete Kecamatan Alam Barajo Kota Jambi.dengan tujuan untuk mengetahui sisi ekonomi usahatani seperti (Pendapatan,R/C ratio,Break Event Poin /BEP dan Payback Period/PP). Hasil penelitian memperlihatkan rata-rata penerimaan sebesar $\mathrm{Rp}$ 13.976.351,-/MT dengan rata-rata pendapatan sebesar Rp13.703,931,-/MT,nilai R/C Ratio sebesar 51,3 dan hasil perhitungan $\mathrm{R} / \mathrm{C}$ ratio ini menunjukkan bahwa usahatani singkong yang dilakukan petani memperoleh keuntungan dan layak untuk diteruskan, dengan kata lain bahwa dengan modal sebesar Rp272.420,- diperoleh hasil penjualan sebesar 51,3 kali atau setara dengan Rp 13.796.351,-/MT. BEP produksi hasil perhitungan sebesar $90,80 \mathrm{Kg} / \mathrm{MT}$ yang memperlihatkan bahwa produksi terendah yang harus dihasilkan oleh petani adalah sejumlah 90,80 $\mathrm{Kg} / \mathrm{MT}$ agar usahatani tidak mengalami kerugian sedangkan BEP harga sebesar $\mathrm{Rp} 58,4,-/ \mathrm{Kg}$, artinya dengan harga $\mathrm{Rp} 58,4,-/ \mathrm{Kg}$ petani sudah dapat mengembalikan modal usaha,sedangkan hasil perhitungan dari PP sebesar 0,05 yaitu kecil dari rata-rata umur ekonomis alat yang digunakan $(7,8$ MT) dengan demikian waktu yang diperlukan untuk mengembalikan investasi tidak sampai 7,8 MT.
\end{abstract}

Kata Kunci : Tinjauan ekonomi,Usahatani, Singkong.

Diterbitkan oleh Program Studi Agribisnis Fakultas Pertanian Universitas Batanghari Jambi Halaman 62 


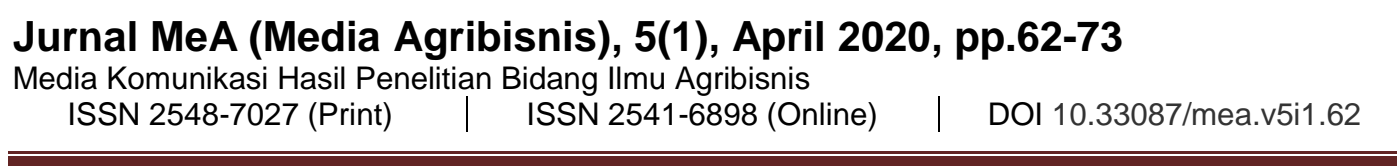

\section{PENDAHULUAN}

Singkong merupakan tanaman pangan yang penting setelah padi,jagung dan kacang-kacangan, sebagai pengganti beras sebagai sumber korbohitrat, selain itu singkong juga sebagai bahan diversifikasi pangan yang banyak disenangi konsumen terutama yang menjalani program diet karbohidrat,bahan baku industry dan bahan baku bioetanol dengan sifat tanaman yang mempunyai adaptasi yang luas sehingga mudah dibudidayakan disemua tempat, umbinya dapat bertahan lama dalam penyimpanan asalkan sewaktu memotongnya membiarkan tangkainya ikut dan tidak memerlukan perlakuan khusus dalam penyimpanan, disamping rasanya yang enak dapat dibuat berbagai olahan sehingga dengan demikian akan membuka peluang usaha yang dapat menyerap tenaga kerja dan secara tidak langsung berkontribusi dalam mengurangi angka pengangguran sejalan dengan pendapat Soekartawi (1993),suatu usaha pertanian diarahkan untuk meningkatkan produksi guna memenuhi kebutuhan pangan dan kebutuhan industri dalam negri,meningkatkan pendapatan petani,memperluas kesempatan kerja.

Provinsi Jambi yang terdiri dari 11 Kabupaten/Kota yang merupakan penghasil singkong,salah satunya Kabupaten/Kota Jambi dengan luas panen 132 Ha, produksi sebesar 3.281 Ton dan produktivitas sebesar 24,85 Ton /Ha Tahun 2018. Kecamatan Alam Barajo yang berada di Kota Jambi memiliki luas panen singkong sebesar 79 Ha,produksi sebesar 1.960 Ton dan Produktivitas 24,87 Ton/Ha yang menempati posisi tertinggi diKota Jambi. Kelurahan Bagan Pete merupakan salah satu Kelurahan yang berada di Kecamatan Alam Barajo memiliki posisi tertinggi dari Kelurahan lainnya di Kecamatan Alam Barajo dengan luas tanam 43 Ha,Produksi sebesar 1.073 Ton dengan produkyivitas sebesar 24,95 Ton / Ha pada tahun 2018. Keberhasilan yang dapat diraih oleh usahatani singkong di Kelurahan Bagan Pete dapat diukur dengan mengetahui besarnya pendapatan yang diperoleh petani.

Berdasarkan penjelasan latar belakang maka dapat dibuat rumusan masalah yaitu Bagaimana gambaran kegiatan usahatani singkong mulai dari hulu hingga hilir dan bagaimana kondisi usahatani singkong di Kelurahan Bagan Pete dilihan dari sisi ekonomi (Pendapatan, $\mathrm{R} / \mathrm{C}$ rasio,BEP dan PP). Adapun tujuan dari penelitian ini adalah Menggambarkan kegiatan usahatani singkong dari hulu, on farm dan hilir serta menganalisis kondisi ekonomi usahatani singkong (yaitu Pendapatan, R/C rasio, BEP dan PP). Berdasarkan uraian diatas penulis tertarik untuk melakukan penelitian dengan judul "Usahatani Singkong (Manihot utilissima) di Kelurahan Bagan Pete Kecamatan Alam Barajo Kota Jambi Ditinjau Dari Sisi Ekonomi”.

Diterbitkan oleh Program Studi Agribisnis Fakultas Pertanian Universitas Batanghari Jambi Halaman 63 


\section{Jurnal MeA (Media Agribisnis), 5(1), April 2020, pp.62-73 \\ Media Komunikasi Hasil Penelitian Bidang IImu Agribisnis ISSN 2548-7027 (Print) | ISSN 2541-6898 (Online)

\section{METODOLOGI PENELITIAN}

Kelurahan Bagan Pete di Kecamatan Alam Barajo Kota Jambi merupakan Lokasi penelitian yang dipilih secara sengaja (purposive) dengan pertimbangan Kelurahan ini merupakan sentra produksi singkong,penelitian difokuskan pada gambaran kegiatan usahatani mulai dari aspek hulu,produsi ,aqspek hilir,pendapatan, $\mathrm{R} / \mathrm{C}$ rasio,BEP dan $\mathrm{PP}$.

\section{Jenis Data}

Jenis data berdasarkan waktu adalah satu waktu tertentu (Cross section ) sedangkan menurut skala ukur adalah data rasio yang bersumber dari data primer dan sekunder dengan menggunakan metode survai.Menurut Silalahi.U (2010),bahwa servay adalah suatu usaha untuk mendapatkan dan mengumpulkan data dari informasi dari berbagai sumber.

\section{Metode Penarikan Sampel}

Populasi petani singkong berjumlah 73 rumah tangga petani (RTP),jumlah sampel 37 RTP yang diambil 50\% dari jumlah populasi hal ini merujuk pada pendapat Winarno (2004) bahwa bila populasi dibawah 100 dan cukup homogen maka sampel yang diambil berjumlah $50 \%$, bila populasi diatas 100 dapat diambil sampel sebanyak $15 \%$ dan sampel manusia hendaknya diatas 30 orang besarnya. sampel diambil dengan cara acak sederhana (simple random sampling) dengan cara mengundi populasi dan yang terpilih oleh peneliti merupakan sampel. Penggunaan metode siple random sampling ini ber tujuan agar setiap petani memiliki kesempatan yang sama untuk terpilih menjadi sampel (Singarimbun 1982).

\section{Metode Analisis Data}

Untuk mengetahui gambaran kegiatan usahatani dilakukan dengan cara menyederhanakan data yang diperoleh dengan cara tabulasi,persentase dan dianalisis secara deskriftif,kualitatif dalam bentuk narasi sedangkan untuk menjawab tujuan ke dua dilakukan dengan analisis menggunakan beberapa rumus analisis.

Untuk menghitung pendapatan, terlebih dahulu harus dihitung penerimaan dengan menggunkan rumus Samuelson dan Nordhaus (2003) :

$T R=P q \cdot Q$

Dimana:

$\mathrm{TR}=$ Total penerimaan $(\mathrm{Rp} / \mathrm{MT})$

$\mathrm{Pq}=$ Harga produk $(\mathrm{Rp} / \mathrm{Kg})$

$\mathrm{Q}=$ Jumlah Produk $(\mathrm{Kg} / \mathrm{MT})$

$1 \mathrm{MT}=6$ bulan (Umur tanam)

Untuk menghitung biaya variable dengan menjumlahkan seluruh biaya variable yang habis terpakai dalam $1 \mathrm{MT}$, sedangkan untuk menghitung biaya tetap menggunakan rumus penyusutan (Algifari,2001) :

Diterbitkan oleh Program Studi Agribisnis Fakultas Pertanian Universitas Batanghari Jambi Halaman 64 


\section{Jurnal MeA (Media Agribisnis), 5(1), April 2020, pp.62-73}

Media Komunikasi Hasil Penelitian Bidang IImu Agribisnis

$B P A=\frac{D-S}{N}$

Dimana :

$\mathrm{BPA}=$ biaya penyusutan alat $(\mathrm{Rp} / \mathrm{MT})$

$\mathrm{D}=$ Nilai perolehan $(\mathrm{Rp})$

$\mathrm{S}=$ Nilai sisa $(\mathrm{Rp})$ asumsi $=0$

$\mathrm{N}=$ Umur ekonomis (MT)

Untuk menghitung total biaya digunakan rumus Soekartawi (1995) sebagai berikut:

$T C=F C+V C$

Keterangan:

$\mathrm{TC}=$ Total cost atau total biaya $(\mathrm{Rp} / \mathrm{MT})$

$\mathrm{FC}=$ Fixed cost atau biaya tetap $(\mathrm{Rp} / \mathrm{MT})$

$\mathrm{VC}=$ Variavel cost atau biaya variable $(\mathrm{Rp} / \mathrm{MT})$

Sedangkan untuk menghitung pendapatan menggunakan rumus Soekartawi (1990) sebagai berikut:

$P d=T R-T C$

Dimana :

$\mathrm{Pd}=$ Total pendapatan usahatani $(\mathrm{Rp} / \mathrm{MT})$

$\mathrm{TR}=$ Total penerimaan $(\mathrm{Rp} / \mathrm{MT})$

$\mathrm{TC}=$ Total biaya $(\mathrm{Rp} / \mathrm{MT})$

Untuk mengetahui suatu usaha yang dijalankan efisien atau tidak dapat dihitung dengan menggunakan rumus Soekartawi (1995) sebagai berikut :

$\mathrm{R} / \mathrm{C}$ rasio $=$ Penerimaan $/$ biaya produksi

Dimana :

$\mathrm{R}=$ Total penerimaan usahatani $(\mathrm{Rp} / \mathrm{MT})$

$\mathrm{C}=$ Total biaya usahatani (Rp/MT)

Perhitungan ini selain berguna untuk mengetahui efisiensi suatu usaha juga untuk mengetahui besarnya penerimaan yang diperoleh dari tiap rupiah yang dikeluarkan, sehingga dapat diketahui apakah layak dan menguntungkan suatu usaha yang dijalankan dengan kaidah peputusan sebagai berikut :

Jika hasil perhitungan $\mathrm{R} / \mathrm{C}$ rasio $=1$ maka usaha yang dijalankan hanya memberikan manfaat

$\mathrm{R} / \mathrm{C}$ rasio < 1maka usaha yang dijalankan mengalami kerugian.

$\mathrm{R} / \mathrm{C}$ rasio > 1 maka usahaq yang dijalankan menguntungkan dan layak untuk dilanjutkan. 


\section{Jurnal MeA (Media Agribisnis), 5(1), April 2020, pp.62-73}

Media Komunikasi Hasil Penelitian Bidang IImu Agribisnis ISSN 2548-7027 (Print) | ISSN 2541-6898 (Online)

DOI 10.33087/mea.v5i1.62

Selain mengetahui kelayakan suatu usaha yang dijalankan dapat juga diketahui dengan menghitung kapan usaha tersebut pulang pokok/balik modal (Break EventPoint/BEP). Break Event Point adalah suatukeadaan usaha dalam operasinya tidak memperoleh laba dan juga tidakmenderita kerugian atau dengan kata lain total biaya sama dengan total penjualan sehingga tidak ada laba dan ntidak ada rugi. Hal ini bisa terjadi pada usaha dalam operasinya menggunakan biaya tetap dan biaya variable. Apabila penjualan hanya cukup menutupi biaya tetap dan biaya variable. Apabila penjualan hanya cukup menutupi biaya variable dan sebagian biaya tetap, maka usaha menderita kerigian sebaliknya,usaha akan memperoleh keuntungan apabila penjualan melebihi biaya variable dan biaya tetap yang harus dikeluarkan (Mulida,2013).Umar (2005) menyatakan BEP merupakan suatu alat analisis yang digunakan untuk hubungan antar beberapa variable didalam kegiatan suatu usaha,seperti tingkat produksi yang dilaksanakan, biaya yang dikeluarkan serta pendapatan suatu usahadari kegiatannya, pendapatan usaha merupakan penerimaan yang dihasilkan dari kegiatan usaha seperti biaya tetap dan biaya variable. Analisis BEP dapat merencanakan segala sesuatu sebagai berikut:

a. Dapat dihitung beberapa produksi (satuan) yang harus dicapai petani agar memperoleh keuntungan $\mathrm{Rp} x$ atau meuntungan marjin $\mathrm{Rp} x \%$.

b. Dapat dihitung harga jual ( $\mathrm{Rp} / \mathrm{satuan})$ agar petani mendapat keuntungan sebesar Rp $\mathrm{x}$ atas total biaya produksi atau untung sebesar $\mathrm{x} \%$ dari total biaya produksi yang dikeluarkan.

Menurut B. Sarwono (2007) untuk me3nghitung BEP produksi dan BEP harga dapat dirumuskan sebagai berikut :

$B E P$ Produksi $=\frac{\text { Total Biaya }(T C)}{\text { Harga Jual Produk }(P)}$

$B E P$ Produksi $=\frac{\text { Total Biaya }(T C)}{\text { Jumlah Produk }(Y)}$

Dimana:

BEP produksi $=$ Titik balik modal usahatani $(\mathrm{Kg} / \mathrm{MT})$

$\mathrm{BEP}$ harga $=$ Titik balik modal/pulang pokok usahatani $(\mathrm{Kg} / \mathrm{MT})$

$\mathrm{TC}=$ Total biaya usahatani $(\mathrm{Rp} / \mathrm{Kg})$

$\mathrm{P} \quad=$ Harga jual produk $(\mathrm{Rp} / \mathrm{Kg})$

$\mathrm{Y}=$ Jumlah produk $(\mathrm{Kg} / \mathrm{MT})$

Untuk mengetahui berapa lama waktu yang diperlukan untuk mengembalikan modal yang diinvestasikan ke dalam proses produksi dengan membandingkan dengan alat yang dipakai yang ber umur paling singkat.maka dianalisis dengan menggunakan rumus Analisis Payback Period (PP), Husnan dan Muhammad (2000):

Diterbitkan oleh Program Studi Agribisnis Fakultas Pertanian Universitas Batanghari Jambi Halaman 66 
$P P=\frac{\text { Investasi }}{\text { Pendapatan }}$

Dimana:

PP = Payback Period (MT)

Investasi $=$ modal yang ditanamkan $(\mathrm{Rp})$

Pendapatan $=$ Penerimaan - biaya $(\mathrm{Rp} / \mathrm{MT})$

\section{Identitas Responden \\ Umur Petani}

\section{HASIL PENELITIAN}

Umur yang dilalui seseorang biasanya berkaitan erat dengan kemampuan seseorang dalam mengelola suatu usaha, baik dalam bentuk tenaga maupun pikiran yang dicurahkan dalam kegiatan usaha tersebut. Demikian pula dengan petani,semakin tua umur petani maka tenaganya semakin berkurang kondisi ini sangat berbeda dengan petani yang masih muda kemampuan fisik yang masih kuat untuk bekerja, lebih cepat menerima inovasi baru dan lebih berani menanggung risiko hal ini disebabkan oleh petani muda lebih kurang ber pengalamandibandingkan dengan petani yang sudah tua,sehingga untuk memajukan kegiatan usahataninya petani muda harus lebih gesit. Dari hasil penelitian terhadap sampel umur petani berkisar antara 45 tahun sampai 65 tahun dengan rata-rata ber umur 54 tahun, hal ini sejalan dengan pendapat Tuwo (2011) yang menyatakan bahwa umur 54 tahun merupakan tergolong masih produktif dalam menghasilkan barang dan jasa untuk memenuhi kebutuhan hidup. Untuk lebih jelasnya dapat dilihat pada tabel berikut:

Tabel 1. Distribusi Petani singkong berdasarkan umur

\begin{tabular}{cccc}
\hline No & Umur (Tahun) & Persentase & Frekuensi (RTP) \\
\hline 1 & $45-48$ & 3 & 8 \\
2 & $49-52$ & 13 & 35 \\
3 & $53-56$ & 11 & 30 \\
4 & $57-60$ & 7 & 19 \\
5 & $61-64$ & 2 & 5 \\
6 & $65-68$ & 1 & 3 \\
& & 37 & 100 \\
\hline
\end{tabular}

Sumber: Data Primer yang Diolah tahun 2019.

Demikian juga dijelaskan oleh Soeharjo dan patong (1973),umur marupakan factor yang penting dalam proses pengolahan usahatani, produktivitas kerja sangat dipengaruhi oleh umur petani. Pada usia produktif produktivitas kerja akan lebih cepat dibandingkan dengan usia non produktif. Sesuai dengan pendapat Hernanto (1983) bahwa kelompok umur produktif berada pada jenjang 15 - 55 tahun, demikian juga dijelaskan oleh Badan Pusat Statistik (2010), komposisi penduduk Indonesia menurut kelompok umur terdiri dari penduduk usia muda (0-14 tahun), usia produktif (15-64 tahun)dan usia tua ( $\geq 65$ tahun)

Diterbitkan oleh Program Studi Agribisnis Fakultas Pertanian Universitas Batanghari Jambi Halaman 67 
Jurnal MeA (Media Agribisnis), 5(1), April 2020, pp.62-73

Media Komunikasi Hasil Penelitian Bidang IImu Agribisnis ISSN 2548-7027 (Print) | ISSN 2541-6898 (Online)

DOI 10.33087/mea.v5i1.62

\section{Pendidikan petani}

Pendidikan merupakan suatu tahap penting yang harus dimiliki seseorang. Pendidikan merupakan salah satu indicator yang dapat digunakan untuk mengetahu kualitas sumberdaya manusia adalah tingkat pendidikan,sesuai dengan pendapat Sumardi (1997), kemajuan suatu wilayah ditentukan beberapa factor penting yang mencakup kualitas sumberdaya manusia. Dengan tingkat pendidikan yang baik diharapkan akan menunjang kegiatan yang dilakukan terutama dari pola berfikir akan lebih rasional dalam mengambil suatu keputusan, membaca situasi dan kondisi yang sedang dihadapi serta selera konsumen, daya beli konsumen yang dapat digunakan untuk menetapkan harga jual produk yang merupakan tujuan akhir dari suatu usaha yang dijalankan untuk memperoleh pendapatan. Pendidikan petani sampel didaerah penelitian berpariasi dari tingkat SD,SMP dan SMA dan sebagian besar (54\%) tamatan SMA dari 37 petani sampel. Untuk lebih jelasnya dapat dilihat pada tabel berikut ini :

Tabel 2. Distribusi Petani Singkong Berdasarkan Tingkat Pendidikan.

\begin{tabular}{cccc}
\hline No & Tingkat Pendidikan & Persentase & Frekuensi (RTP) \\
\hline 1 & SD & 5 & 14 \\
2 & SMP & 12 & 32 \\
3 & SMA & 20 & 54 \\
& & 37 & 100
\end{tabular}

Sumber: Data Primer yang Diolah tahun 2019.

Dengan tingkat pendidikan yang demikian memungkinkan petani untuk dapat meningkatkan ilmu pengetahuannya yang dapat diperoleh melalui membaca buku - buku pertanian,memperoleh pengetahuan dari internet tentang cara budidaya yang baik dalam menunjang kenajuan kegiatan usaha yang sedang dijalani.Pada umumnya jenis dan tingkat pendidikan dianggap dapat mewakili kualitas tenaga kerja. Pendidikan sebagai penyiapan tenaga kerja diartikan sebagai kegiatan membimbing peserta didik sehingga memiliki bekal dasar untuk bekerja.pembekalan dasar merupakan pembentukan sikap,pengetahuan dan keterampilan kerja pada calon luaran.

\section{Jumlah tanggungan keluarga}

Jumlah anggota keluarga yang menjadi tanggung jawab petani merupakan beban yang harus di penuhi oleh petani sebagai kepala keluarga hal ini sangat mempengaruhi keputusan yang ditetapkan oleh petani dalam menjalani usahanya. Tanggungan keluarga terdiri dari istri,anak serta tanggungan keluarga lain yang tinggal bersama dalam keluarga sekaligus menjadi tanggung jawab kepala keluarga. Untuk lebih jelasnya dapat dilihat pada tabel berikut.

Diterbitkan oleh Program Studi Agribisnis Fakultas Pertanian Universitas Batanghari Jambi Halaman 68 


\begin{tabular}{|c|c|c|c|}
\hline \multicolumn{4}{|c|}{ 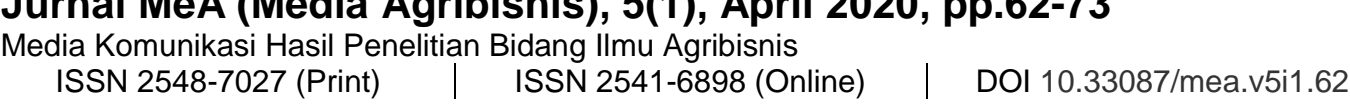 } \\
\hline \multicolumn{4}{|c|}{ Tabel 3. Distribusi petani berdasarkan jumlah tanggunagn keluarga } \\
\hline No & Jumlah Anggota Keluarga & Persentase & Frekuensi (RTP) \\
\hline 1 & 3 & 3 & 8 \\
\hline 2 & 4 & 13 & 4 \\
\hline 3 & 5 & 11 & 30 \\
\hline 4 & 6 & 7 & 19 \\
\hline 5 & 7 & 2 & 5 \\
\hline \multirow[t]{2}{*}{6} & 8 & 1 & 3 \\
\hline & & 37 & 100 \\
\hline
\end{tabular}

Sumber: Data primer yang diolah tahun 2019

Jumlah anggota keluarga yang banyak harus dikelola dengan baik sebagai sumber tenaga kerja keluarga karena dapat meringankan biaya produksi usahatani yang dijalankan,karena tidak perlu mengeluarkan upah tenaga kerja ,tetapi disisi lain petani harus memenuhi kebutuhan yang banyak pula. Hasil penelitian memperlihatkan jumlah anggota keluarga yang merupakan tanggungan petani rata-rata 5 orang.dengan jumlah anggota yang terbilang banyak ini petani sebagai kepala keluarga harus bisa memenenjemen tenaga kerja yang ada dengan baik sehingga tidak terjadi pengangguran yang tersembunyi.

\section{Luas Lahan}

Lahan merupakan salah satu factor produksi yang penting dan berkaitan langsung dengan produksi yang akan dihasilkan, luas lahan adalah luas wilayah yang diusahakan petani untuk kegiatan budidaya tanaman,semakin luas lahan yang diusahakan akan semakin banyak produsi yang dihasilkan dengan menganggap factor lain sateris varibus,lahan yang sempit tentu saja membuat hasil yang diperoleh tidak memadai sehingga pendapatan yang mereka peroleh juga rendah. Untuk lebih jelasnya jumlah lahan yang diusahakan petani dapat dilihat pada tabel berikut:

Tabel 4. Distribusi luas lahan yang diusahakan petani sampel

\begin{tabular}{cccc}
\hline No & Luas Lahan & Persentase & Frekuensi (RTP) \\
\hline 1 & $500-2.976$ & 28 & 76 \\
2 & $2.918-5.335$ & 1 & 3 \\
3 & $5.336-7.753$ & 0 & 0 \\
4 & $7.754-10.717$ & 5 & 13 \\
5 & $10.718-12.589$ & 0 & 0 \\
6 & $12.590-15.007$ & 3 & 8 \\
& Jumlah & 37 & 100
\end{tabular}

Sumber: Data primer yang diolah tahun 2019

Dari tabel diatas terlihat bahwa luas lahan yang dimiliki petani sampel berkisar antara $500 \mathrm{~m}^{2}$ sampai $15.007 \mathrm{~m}^{2}$ dengan rata-rata $3.727 \mathrm{~m}^{2}$ dan sebagian besar 28 RTP (76\%) sampel memiliki luas lahan 500-2.927 $\mathrm{m}^{2}$, luas lahan 7.7547.10.171 $\mathrm{m}^{2}$ sebanyak 5 RTP sampel (13\%)dan luas laha sebesar 12.590-15.007 $\mathrm{m}^{2}$ sebanyak 3 RTP sampel (8\%), dengan luas lahan yang dimiliki ini petani

Diterbitkan oleh Program Studi Agribisnis Fakultas Pertanian Universitas Batanghari Jambi Halaman 69 


\section{Jurnal MeA (Media Agribisnis), 5(1), April 2020, pp.62-73}

Media Komunikasi Hasil Penelitian Bidang IImu Agribisnis ISSN 2548-7027 (Print) | ISSN 2541-6898 (Online)

DOI 10.33087/mea.v5i1.62

dituntut untuk memenuhi kebutuhan keluarga oleh karena itu petani harus benarbenar mengusahakan kebun dengan baik sehingga petani harus memilih bibit yang baik mudah pemeliharaannya dan berproduksi banyak.

\section{Gambaran Usahatani Singkong di daerah Penelitian}

Tanaman singkong dapat dipanen setelah tanaman berumur 6 bulan,bibit yang digunakan petani bibit singkong roti yang diperoleh dari tetangga dan keluarga yang telah mengusahakan lebih dulu sehingga didalam perhitungan biaya bibit tidak dikeluarkan petani hal ini dapat meringankan petani dari sisi biaya usahatani. Peralatan seperti cangkul,parang,sabit dan hand sprayer serta pupuk dan obat-obatan diperoleh dengan cara membeli di toko pertanian.terdekat sehingga petani lebih pokus dalam mejalankan usahanya karna waktu yang digunakan untuk memperoleh bahan -bahan yang diperlukan tidak banyak.

Sebelum menanam tanah dicangkul rata dan diberi pupuk kandang dengan jumlah rata-rata 8 karung /MTdengan harga Rp 10,-/karung, kemudian dibiarkan selama 4-7 hari hal ini bertujuan agar pupuk terurai dan menyatu dengan tanah, selain itu diharapkan akan adanya embun dan hujan yang dapat mengurangi panas dari pupuk tersebut.Setelah 4-7 hari dibiarkan kemudian ditanami bibit singkong dengan ukuran bibit 10-15 cm dan jarak tanam $50 \mathrm{Cm}$ x $50 \mathrm{Cm}$. Pengendalian hama dilakukan pada saat ada serangan hama seperti hama babi, pengendalian gulma cukup dilakukan dengan cara membersihkan dengan menggunakan parang dan sabit dan pembersihan ini tidak hanya diareal kebun saja tetapi sampai dipinggir dari areal kebun juga dibersihkan sehingga apabila serangan hama datang petani tidak menginjak tanaman tetapi cukup dengan melewati dipinggir areal tanaman sedangkan tanaman tidak terganggu selain itu kondisi kebun yang bersih akan memudakhan petani untuk mengotrol kebunnya dari jarak jauh.Pemupukan NPK diberikan pada saat tanaman berumur 2,5 bulan dengan rata-rata pemberian $19 \mathrm{Kg} / 0,372 \mathrm{Ha} / \mathrm{MT}$.

Tanaman singkong setelah berumur 6 bulan dapat dipanen hasilnya dengan cara mencabut batang singkong dan dibersihkan umbinya dari tanah yang menempel kemudian dipisahkan dari tangkainya, rata produksi sebanyak 4.569 $\mathrm{Kg} / \mathrm{MT}$. Kemudian dipasarkan petani melalui agen dan terkadang konsumen mendatangi rumah petani atau dipusat produksi dengan membawa karung sendiri sehingga biaya produksi karung tidak diperhitungkan,sebagai modal petani, penetapan harga jual untuk ke tiga tempat ini baik pada agen, ditempat produksi (kebun) maupun dirumah diberlakukan sama yaitu rata-rata $\mathrm{Rp} 3000,-$ / Kg

Peneriman usahatani singkong rata-rata sebesar Rp 13.976.351,-/MT yang diperoleh dari perkalian antara jumlah rata-rata prodksi $(4.659 \mathrm{Kg} / \mathrm{MT})$ dengan

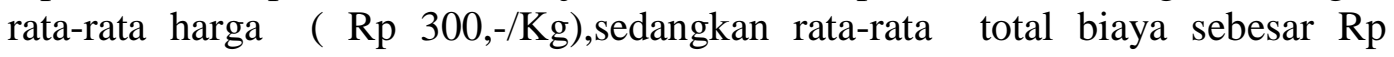
272.420,-/MT (biaya tetap sebesar Rp 89.220,-/MT + biaya tidak tetap sebesar Rp 183.200,-/MT),Penggunaan rata-rata biaya terbesar pada komponen biaya tetap adalah pada alat hand Sprayer (Rp 40.090,-/MT) dan pada rata-rata biaya tidak tetap adalah pada pemakaian pupuk NPK (Rp 93.176,-/MT).untuk lebih rinci ratarata komponen biaya dapat dilihat pada tabek berikut ini.

Diterbitkan oleh Program Studi Agribisnis Fakultas Pertanian Universitas Batanghari Jambi Halaman 70 


\begin{tabular}{|c|c|c|c|}
\hline \multicolumn{4}{|c|}{ 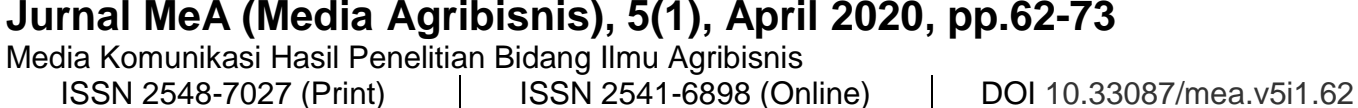 } \\
\hline \multicolumn{4}{|c|}{ Tabel 5. Rata-rata Jumlah Komponen Biaya Produksi tahun 2019} \\
\hline No & Uraian Komponen Biaya & Jumlah (Rp/MT) & Persentase $(\%)$ \\
\hline \multirow[t]{5}{*}{1} & Biaya Tetap & 89.220 & 33 \\
\hline & 1. Cangkul & 17.372 & 6,3 \\
\hline & 2. Hand Sprayer & 40.090 & 14,7 \\
\hline & 3. Parang & 16.766 & 6,1 \\
\hline & 4. Sabit & 17.992 & 5,5 \\
\hline \multirow[t]{5}{*}{2} & Biaya Tidak Tetap & 183.200 & 67 \\
\hline & 1. Pupuk Kandang & 75.676 & 28 \\
\hline & 2. Pupuk NPK & 93.176 & 34 \\
\hline & 3. Obat-obatan & 14.139 & 5 \\
\hline & $\begin{array}{c}\text { Jumlah Total (Total } \\
\text { biaya) }\end{array}$ & 272.420 & 100 \\
\hline
\end{tabular}

Sumber: Data Primer yang diolah,2019

Setelah diperoleh perhitungan rata-rata penerimaan selanjutnya dapat dihitung rata-rata pendapatan sebesar Rp 13.703.931,-/MT yang merupakan selisih antara penerimaan dengan total biaya yang dikeluarkan selama 6 bulan dan jika kita perhitungkan lagi maka pendapatan petani dalam 1 bulan sebesar Rp 2.630.162,-/bulan, pendapatan yang diperoleh petani ini masih jauh dibawah UMR Upah Minimum Regional (Tahun 2020)

Hasil perhitungan $\mathrm{R} / \mathrm{C}$ ratio sebesar 51,3 yang diperoleh dari hasil perhitungan sebagai berikut :

Tabel 6. R/C ratio usahatani singkong Kelurahan Bagan Pete Tahun 2019

\begin{tabular}{cc}
\hline Uraian & Jumlah $(\mathrm{Rp} / \mathrm{MT})$ \\
\hline Total penerimaan & 13.976 .351 \\
Total biaya & 272.420 \\
R/C rasio & 51,3 \\
\hline
\end{tabular}

Sumber: Data primer yang diolah Tahun 2019.

Perhitungan $\mathrm{R} / \mathrm{C}$ rasio ini dapat dipakai sebagai ukuran efisiensi dari suatu usaha yang dijalankan petani dengan membandingkan terhadap kaidah yang ditetapkan pada rumus Soekartawi (1995), yaitu jika hasil perhitungan lebih besar dari 1maka usaha yang dijalankan memperoleh keuntungan dan ini juga dapat dilihat dari pemdapatan yang diperoleh petani yaitu jumlah penerimaan yang diperoleh dapat mengembalikan total biaya yang dikeluarkan selama satu kali musim tanam. Demikian juga dijelaskan oleh Faliatra (2000), RC rasio ditentukan pada criteria-kriteria investasi yang pengukurannya diarahkan pada suatu usaha memperbandingkan, mengukur, serta menghitung tingkat keuntungan suatu usaha atau untuk menentukan keberhasilan suatu usaha.

Sedangkan untuk mengetahui berapa produksi minimal yang harus dihasilkan petani dan harga jual terendah yang harus diperoleh petani agar memperoleh keuntungan, dapat ditentukan dengan perhitungan BEP Produksi dan BEP Harga. Dari hasil perhitungan diperoleh BEP produksi sebesar 90,80 Kg/MT dan bila dibandingkan dengan rata-rata produksi yang dihasilkan petani yaitu

Diterbitkan oleh Program Studi Agribisnis Fakultas Pertanian Universitas Batanghari Jambi Halaman 71 


\section{Jurnal MeA (Media Agribisnis), 5(1), April 2020, pp.62-73}

Media Komunikasi Hasil Penelitian Bidang IImu Agribisnis ISSN 2548-7027 (Print) | ISSN 2541-6898 (Online)

DOI 10.33087/mea.v5i1.62

sebesar $4.659 \mathrm{Kg} / \mathrm{MT}$ maka produksi yang dihasilkan jauh lebih besar, hal ini menandakan bahwa dengan besar produksi tersebut petani akan memperoleh keuntungan, sedangkan hasil perhitungan BEP harga sebesar $\mathrm{Rp} 58,4,-/ \mathrm{Kg}$ dan harga jual ditingkan petani jauh melebihi harga minimal yang ada yaiyu Rp 3000,/Kg kondisi ini menandakan usaha yang dijalankan petani cukup menguntungkan untuk dilanjutkan.

Untuk mengetahui berapa lama waktu yang digunakan untuk mengembalikan modal yang ditanam dalam proses produksi dapat dilihat dari hasil perhitungan Payback Priod (PP) dan membandingkannya dengan umur ekonomis terendah dari alat yang digunakan dalam proses produksi, dari hasil perhitungan diperoleh PP sebesar 0,05 jika dibandingkan dengan umur ekonomis rata-rata alat yang digunakan $(7,8 \mathrm{MT})$ maka PP hasil perhitungan jauh lebih kecil dari umur terendah rata-rata alat yang digunakan kondisi ini menandakan bahwa dalam tempo 0,05 MT sudah dapat mengembalikan investasi yang digunakan dalam proses produksi dengan kata lain sisa watu dapat diperhitungkan sebagai keuntungan dari alat yang digunakan.

\section{KESIMPULAN}

Dari hasil perhitungan dan pembahasan dapat disimpulkan bawa :

1. Rata-rata luas lahan yang diusahakan petani $3.727 \mathrm{M} 2(0,372 \mathrm{Ha})$ dengan jarak tanam singkong yaitu $50 \mathrm{Cm}$ x $50 \mathrm{Cm}$, pemupukan menggunakan pupuk kandang dan NPK, obat-obatan dilakukan satu kali dalam satu musim tanam, sedangkan pemberantasan hama dilakukan pada saat ada serangan, tenaga kerja bersumber dari dalam keluarga.

2. Rata-rata penerimaan sebesar Rp. 13.976.351,-/MT, rata-rata biaya produksi sebesar Rp 272.420,-/MT, Pendapatan yang diperoleh petani rata-rata sebesar $\mathrm{Rp}$ 13.703.931,-/MT,R/C rasio sebesar 51,3. BEP produksi sebesar 90,80 $\mathrm{Kg} / \mathrm{MT}$, BEP harga sebesar Rp 58,4,-/Kg. 


\section{Jurnal MeA (Media Agribisnis), 5(1), April 2020, pp.62-73}

Media Komunikasi Hasil Penelitian Bidang IImu Agribisnis

\section{DAFTAR PUSTAKA}

Alves A.A.C (2002).Daun Singkong dan Pemanfaatannya Terutama Sebagai Pakan. Universitas Pajajaran. Bandung.

Adiwilaga A.2011. Ilmu Usahatani.Penerbit Alumni. Bandung.

Badan Pusat Statistik.2010. Data statistic Indonesia Jumlah Penduduk Menurut Kelompok Umur, Jenis Kelamin, Provinsi,Dan Kabupaten/ Kota,2005

Husnan.S dan Muhammad S.2000.Study Kelayakan Proyek.Unit Penerbit dan percetakan AMP YKPN.Yokyakartas

Hernanto.F.1989.Ilmu Usahatani Penebar Swadaya.Jakarta.

Samuelson dan Norhaus. 2003.Ilmu Micro Ekonomi. Media Global Edukasi.Jakartas

Soekartawi.1990. Teori Ekonomi Produksi Dengan Produk Bahasan Analisis Fungsi Coob-Douglas.PT.Raja Grafindo Persada Jakarta

1995.Analisis Usahatani .Penerbit Universitas Indonesia. Jakarta

Singarimbun.1982. Metode Penelitian Survay. LP3ES. Jakarta. Soeharjio dan Patong.1973.Sendi-Sendi Pokok Ilmu Usahatani. Departemen Ilmu-Ilmu sosial Ekonomi Pertanian,IPB.Bogor.

Sarwono.2007.Budidaya Ubijalar. Penerbit Swadaya. Jakarta

Tuwo.M Akib.2011. Ilmu Usahatani Teori dan Aplikasi Menuju Sukses.Press.Kendari.

Winarno.S.1994. Pengantar penelitian ilmiah (dalam metode tehnik). Penerbit Kanisius, Bandung. 